\title{
ГОГОЛЬ І ШЕВЧЕНКО В ЗАРУБІЖНІЙ ТРАНСКРИПЦІЇ
}

Ідеться про недостатньо прояснені проблеми художнього стилю Гоголя ци Шевченка. Автор звернув увагу на них у зв'язку з відзначенням 200-літніх ювілеїв обох українських геніїв, наголосив на дискусійності питань, пов'язаних із їхньою приналежністю до різних стильових епох та національних літератур. Зачеплено також проблему відлуння творчості письменників у літературному зарубіжжі.

Ключові слова: стиль творчості, начіональні риси, бароко, романтизм, реалізм, фольклор, літера урне зарубіжжя.

Речь идёт о недостаточно изученных вопросах стиля творчества Гоголя $u$ Шевченко. Автор обратил внимание на актуализаџию этих проблем в связи с 200-летними юбилеями обоих украинских писателей, указал на дискуссионности суждений о принадлежности их к разным стилевым эпохам и национальным литературам. Затронут также вопрос о восприятии творчества писателей в литературном зарубежье.

Ключевые слова: стиль творчества, национальные черты, барокко, романтизм, реализм, фольклор, литературное зарубежье.

This article discusses deficiencies in stylistic studies of Gogol and Shevchenko. The author highlighted to these prevailing issues in connection with the 200th anniversary of both Ukrainian writers, also it was pointed out in the discussion about how they belong to different stylistic periods and national literatures. The author also touched upon the issue of perception of literary creativity of writers abroad.

Keywords: creative style, national characteristics, baroque, romanticism, realism, folklore, literature abroad.

Історія приналежності літературного генія до певної нації чи навіть до певного міста-села така ж давня, як і сама історія літератури. Сім грецьких міст, наприклад, досі претендують на те, щоб Гомер «народився» саме в їхньому місті; зате ніхто не сперечається, що він таки грецький поет. Тим часом московські літературознавці понад двісті років переконують один одного, що поема невідомого автора «Слово про Ігорів похід» належить таки їхній, московській літературі, хоча всьому світові відомо: в час написання цього твору ніякої Московії на будь-якій мапі світу не існувало; автор цього твору жив або в Києві, або в Новгород-Сіверську, або навіть у Галичині; тобто - на території сучасної України-Русі, але ніяк не Московії...

Iз визначенням національної приналежності Шевченка й Гоголя доходило, бува, до анекдотизму: в 60-х роках минулого вже століття один із 
академічних науковців зараховував Тараса Григоровича до російських письменників тільки тому, що він російською мовою списав значно більше... кілограмів паперу, ніж українською (!). Що ж до Гоголя, то в це питання найбільше плутанини вніс чи не сам автор «Вечорів...» і «Тараса Бульби». У листі до О. Смирнової (1844, 24. ХІІ) він писав: «... Насчёт того, какая у меня душа, хохлацукая или русская... сам не знаю...». Хоча для науки подібні висловлювання не мають ніякого значення, російські літературознавці тим часом переконані на всі сто відсотків: i душа в Гоголя російська, i він $\epsilon$ класиком тільки російської літератури. Коли ж заходить мова про дискусійність цього питання, то в російській пресі можуть з’явитися лише іронічні публікації на зразок тієї, яку помістив порівняно нещодавно портал «ГУЛЯЙ-ПОЛЕ» після російської екранізації «Тараса Бульби»: «Как хохльл и москали Гоголя делили». Ліна Костенко, як знаємо, в той же, приблизно, час у романі «Записки українського самашедчого» написала 3 цього приводу ніби ухильно, але й 3 переконливим натяком: «Гоголь - ц̧е російський письменник, але цุе украӥнський геній. На перший погляд, так просто. А якщуо вдуматись?» [http://ukrkniga.org.ua/ukrkniga-text/794/].

Справді, а якщо вдуматись? Зарубіжні видавці й філологи 3 самого початку ознайомлення 3 творчістю цих двох геніїв висловлювалися ніби однозначно, але й 3 певними застереженнями. У збірнику «Новые стихотворения Пушкина и Шевченки», що вийшов у Лейпцігу ще за життя Тараса Шевченка (1859), редактор його помістив перед публікацією творів автора «Кобзаря» таку примітку: «Следующче стихотворения были нам присланы на малороссийском языке с примечанием, что стихи Шевченко выражение всеобщих, накипевщих слёз; не он плачет об Украйне - она сама плачет его голосом» [Новые стихотворения Пушкина и Шевченко 1859:7]. За рік перед цим у Франції вийшли в перекладі Еж. Моро «Мертві душі» Гоголя 3 таким зауваженням перекладача: цього автора можна назвати російським Бальзаком чи російським Мольєром [http://www.dissertac.com/content/nvgogol...]. Про українськість Гоголя вперше заговорив чи не Йосип Омелянович 
Мандельштам - російський історик літератури, що працював професором Гельсінського університету у Фінляндії. 1902 року у студії про стиль Гоголя він наголосив: мовою душі письменника була таки мова украӥнська; не тільки лексика й семантика, але й синтаксис цього письменника був суто українським; писав він (Гоголь) російськими словами... «перекладаючи» їх 3 українських [Мандельштам 1902:213]. Як Бернард Шоу свою англійську мову «перекладав» 3 ірландської, Еміль Верхарн французьку з рідної йому фламандської і т. д. I. Мандельштам як учений дуже добре усвідомлював, що він говорить у зв’язку з українською мовою: знання ії були в нього органічними, оскільки жив він протягом тривалого часу в Україні i навчався, зокрема, в Харківському університеті.

У світовій літературі непорозуміння 3 національною приналежністю того чи того письменника непоодинокі: не розв’язаним, наприклад, досі вважається питання 3 Джозефом Конрадом, який народився в Україні, батьки його були поляками, але писав він англійською мовою. То чий він письменник? Поляки (нишком і безапеляційно) переконані, що він їхній. Так, як росіяни вважають В. Набокова тільки російським, хоча він писав і англійською мовою. Певна частина білорусів трактують Адама Міцкевича не як польського, а як білоруського письменника, бо $є$ в нього й самохарактеристика: він, мовляв, співець «Литви-Білорусії». Але поляки, звичайно, нізащо не погодяться 3 тим, що він - не їхній поет. Так само росіяни не віддадуть нікому Фонвізіна, Жуковського, Грибоєдова, Пушкіна, Лермонтова, Толстого, Короленка, Чехова, Маяковського чи Буніна. Хоча за походженням усі вони далеко не російські: Фонвізін - німець, Жуковський - по матері - турок, Грибоєдов - поляк, Пушкін - арап, Лермонтов - шотландець, Толстой - скандинав, Чехов - 3 українців, Бунін - польсько-український шляхтич (ім’я в нього - Ян, а не Іван!), Маяковський - 3 запорозьких козаків і т. д. I, відповідно, кров у їхніх жилах тече або турецька, або німецька, або українська (козацька). Письменник же, на думку найбільшого модерніста XX ст. Дж. Джойса, пише завжди не про те, що в нього в голові, а про те, що в нього в крові. 
У матеріалах, які публікувалися чи фільмувалися до 200-ліття Шевченка, можна було натрапити на припущення, що його кров теж була не тільки українською. Автори одного з «документальних» фільмів стверджували, що до його народження причетний якийсь ловелас із... царської сім'ї. Тому, мовляв, i обличчя в нього не «кріпацького», а таки «благородного» походження. Є свідчення, що Великий Карл (Карл Брюллов) узяв Шевченка в свій клас в Академії художеств саме тому, що звернув увагу на його «благородний» вираз обличчя. Думається, що частка якоїсь правди в цьому є, бо без середньої освіти, якої Шевченко не мав, стати студентом Академії навряд чи можна було. Чи відбилося все це у творчості поета й художника? Дехто каже, що так: ненависть до москалів-ловеласів, які перетворювали чорнобривих українських дівчат на покриток («Катерина»), сатирична «поетизація» царської сім’ї («Сон»), порівняння царів із псарями («O люди, люди-небораки...») та характеристика їх як «помазаників божих» і представників «вінщеносної громади» - усе це, мовляв, вияви генетичної пам'яті-помсти поета тому кривднику, що причетний був до його народження. Ця помста інколи набувала в поета міжнародного звучання:

В непробудимому Китаї,

В Сгипті темному і в нас,

I понад Індом і Свфратом...

Дрібніють люде на землі,

Pостуть і висяться изарі.

Автор «Тараса Бульби» заходив у «міжнародні сфери» переважно 3 іронічним пером. Як, скажімо, в «Записках божевільного». Герой цієї повісті свої «божевільні» міркування часом поширював на ті краї, про які міг знати хіба що з якихось майже міфічних джерел: «Говорят, в Англии выплыла рыба, которая сказала два слова на таком странном языке, что ученые уже три года стараются определить и ещё до сих пор ничего не открыли»; «Я открыл, что Китай и Испания совершенно одна и та же земля, и только по невежеству считают их за разные государства. Я советую всем нарочно написать на бумаге Испания, то и выйдет Китай»; «Луна ведь обыкновенно делается в Гамбурге; и прескверно делается. Я удивляюсь, как не обратит на 
это внимание Англия...» і т. п. Найбільш «іноземними» для Гоголя видавалися, проте, російський Петербург і містечкова провінція Росії. Він писав про них із такою негацією, що дехто 3 критиків вбачав у цьому вияви «хохлацької» ненависті до росіян. От, мовляв, коли пише Гоголь про хохлів-малоросів, то всі вони в нього романтично піднесені і героїчні («Вечори...», «Тарас Бульба» й ін.). А от «чисті» росіяни в нього - всуціль відворотні. Всі оті Плюшкіни, Собакевичі, Коробочки... Насправді, як помітив ще Є. Маланюк, вони тільки прізвища мають російські, а самі є представниками суто української еліти [Маланюк 1962:197]. Вживаючи це слово, С. Маланюк брав його в лапки, але й наголошував: немає чого дивуватися, адже інакшої еліти в Україні тоді просто не існувало. Що означає «тоді»? Гоголь жив і творив в епоху, яку прийнято називати романтичною (до середини XIX ст.), однак він внутрішньо залишався людиною епохи попередньої - барокової. А барокова епоха - це (на території Російської імперії) суто український феномен. «Чиста» Росія суто «своїх» барокових героїв не мала за визначенням; вона «проспала», як скаже Д. Чижевський, i ренесанс, i бароко, а свою літературну традицію започаткувала тільки в часи класицизму. Те, що називається російською літературною традицією в докласицистичний період, було або грецьким (Максим Грек), або білоруським (Симеон Полоцький), або українським (Мелетій Смотрицький, Дмитро Туптало, Феофан Прокопович). Добре відомі Ломоносов, Державін чи Тредіаковський, які (прийшовши в російську літературу в середині та в другій половині XVIII століття) не могли, звичайно, залишатися поза цілковитим впливом бароко (в системі віршування, зокрема), але як зрілі письменники вони були класицистами і за мотивами творчості, і за жанровими вподобаннями. Класицистичні жанри «оду» та «елегію» підхопив від них навіть молодий О. Пушкін, аж поки П. В'яземський не звернув його увагу на англійця Байрона; той уже писав суто романтичні поезії та романи в віршах, а ти, мовляв, досі залишаєшся в класицизмі...

М. Гоголь не створив жодного класицистичного твору i тому не міг пристати до будь-якої російської традиції; він започаткував свою, бароково- 
романтичну, 3 якої, по суті, почався абсолютно новий етап у російській літературі. Та чи російській? До власне гоголівської традиції пристали згодом i Тургенєв, і Достоєвський, і інші російські автори, зізнавшись: усі ми вийшли 3 гоголівської «Шинелі». Досі не встановлено тільки, хто першим сказав цю знамениту фразу: Тургенєв чи Достоєвський? А найпослідовнішим продовжувачем гоголівської літературної традиції в другій половині XIX століття випало бути таки «чистому» росіянину М. Салтикову-Щедріну. Висловлювання Т. Шевченка у зв’язку з цим загальновідоме: «Я благоговею перед Салтыковым. О Гоголь, наш бессмертный Гоголь! Какою радостию возрадовалася бы благородная душа твоя, увидя вокруг себя таких гениальных учеников своих. Други мои, искренние мои! Пишите, подайте голос за эту бедную, грязную, опаскуженную чернь! За этого поруганного бессловесного смерда» [Кент 1964:93].

Тарас Шевченко цю думку свою не підтверджував якимись аналітичними спостереженнями. Він відчував іï інтуїтивно і саме як український за типом творчості митець. Українськість відчувалася йому i в гоголівському типі творчості; це помітно було, зокрема, в художній ілюстрації ним повісті «Тарас Бульба» (картина «Зустріч Tараса Бульби з синами»), у його висловлюваннях про Гоголя в листі до Варвари Репніної («Перед Гоголем должно благоговеть как перед человеком, одарённым самым глубоким умом и самою нежною любовью к людям... Наш Гоголь - истинный ведатель сердияа человеческого! Самылй мудрый философ» [Шевченко 2003:54], але найбільше - у вірші «Гоголю», написаному ще за життя автора «Мертвих душ». Ставлю на цьому особливий наголос у зв’язку 3 недавнім виходом у Москві збірки віршів «Небесный огонь», яка містить численні твори, що присвячені саме Гоголю. Більшість їх створена після смерті автора «Мертвих душ», окремі 3 них (зокрема й зарубіжних поетів) відверто графоманські, а от на згаданий твір Тараса Шевченка «Гоголю» упорядники збірки уваги чомусь не звернули. Можливо, через дуже негативну характеристику імперської Росії в цьому творі 
та однаково негативне ставлення до неї обох геніїв; відмінним був лише тип реакції на ту негацію: в одного - сміх, а в другого - плач:

Всі оглухли - похилились

В кайданах... байдуже...

Ти смієшся, а я плачу,

Великий мій друже.

Не виключено, що упорядники спостерегли й разючу однаковість художнього думання (стилю) обох геніїв; а цього імперсько-російські літератори не хотіли визнавати ні в минулому, ні сьогодні. Для них Гоголь реаліст і не більше [Гуковский 1959].

А тут треба було говорити про бароково-романтичну форму письма i Гоголя, і Шевченка, про отой карикатурний погляд першого на згадувану провінційну еліту («Мертві душі»), а другого - на саму вершину імперської влади $з$ ії царем-ведмедем та царицею-опеньком, що «на лихо, сердешнеє, хита головою» («Сон»). Крім «карикатурності», поетика і Гоголя, і Шевченка багата також іншими суто бароковими «примхами»: скажімо - «чудернацтво» в зображенні певних явищ і людських якостей. Про «червону свитку» в ранніх «Вечорах...» Гоголя можна й не згадувати; це - хрестоматія. Більш переконливий аргумент тут - Гоголівський «Ніс»: як міг звичайний людський ніс відділитися від свого господаря i самостійно мандрувати Невським проспектом - на таку метаморфозу в творчості здатні були тільки барокові автори. Подібне спостерігаємо і в повісті Гоголя «Портрет»: виставлений на «вернісажі» портрет незнайомого в цій повісті дивиться тільки на тебе, в якому б місці ти не опинився... Чи не чудернацтво? У Шевченка подібні «незвичайності» спостерігалися вже в ранніх «Гайдамаках» (спрощено кажучи - повний відхід від життєвої правди, зокрема в сцені згуби синів Гонти), а в пізніших творах ними сповнені були і мотиви біблійного характеру («Саул»), і образні структури, що взяті безпосередньо 3 реальної свідомості сучасних поетові українців («Відьма», «Сова»). В останньому творі мати-вдова 
«перевтілена» в сову, а у «Відьмі» - в нафантазовану людською свідомістю «чародійку», яка в поемі стала такою внаслідок великої наруги над нею.

Своєрідними були стосунки барокових авторів із народною піснею та загалом - iз фольклором. Про це написано, звичайно, багато, але - не в суто бароковому плані. На кожному кроці якась приповідка чи й шмат народної пісні - це «придумали» саме творчі люди барокової епохи. А гляньмо на «Вечори...» та «Миргород» Гоголя! Вони вщерть усіяні народними піснями та легендами, а згодом - i фрагментами 3 професійної української літератури («Енеїда» I. Котляревського, «Пан та собака» П. Гулака-Артемовського й ін.). Усіяні не заради орнаменту, а з точною вказівкою на джерело, з якого Гоголь виростав, і в ім’я того типу художнього думання, який сформований в епоху бароко.

У Шевченка він поставав ще більш органічним і більш романтизованим, ніж у Гоголя. Йдеться про те. що романтична харизма (якщо можливий такий вираз) у Шевченка ставала винятково домінуючою і його текст унаслідок цього не просто виявляв зв'язок з фольклорною стихією, а сам поставав як народний мелос. Не випадково композитори масово клади той Шевченків мелос на ноти (інтернетресур подає нині 178 пісенних текстів Кобзаря), а окремі з них ніби й не потребували спеціальної музичної інтерпретації, оскільки мелодика, пісенність були головною рисою їхньої структури як мистецького утвору («Плавай, плавай, лебедоньку...», «Бандуристе, орле сизий...», «У гаю-гаю вітру немає...» та ін.).

3 бароковою епохою пов’язують містичний елемент у творчості романтиків (Д. Чижевський вважав Гоголя одним iз найбільших містиків у світовій літературі) та активізацію в ньому теоцентризму. Більш властивий середньовічному мистецтву, теоцентризм у часи ренесансу похитнувся в бік секуляризації, а в епоху бароко став знову повертатися в центр. Романтики надали йому лиш більш олюдненого характеру, а в Гоголя і Шевченка зробили, по суті, рушієм їхньої естетики. I краса, і добро в цьому світі - виключно від Бога, наголошували обидва. Різниться в них тільки персоніфікація Його: у 
гоголя Він виключно християнський, а в Шевченка - всегальний. «Ми віруєм Твойй силі / i духу живому. / Встане правда, встане воля ! / І Тобі одному / Помоляться всі язики / Вовіки і віки» («Кавказ», виділено мною. - М.Н.).

Коли говорять про Шевченка й Гоголя як письменників світового масштабу, то враховують, звичайно, все: i стильову особливість їхньої творчості, і високий концентрат у їхніх творах філософії добра й крси, але, мабуть, у першу чергу - відтворення прагень людини проникнути якнайглибше в душу самої себе, сприяти розвитку земної і всесвітньої цивілізації. Шукаючи відповіді на ці питання, «світовий» читач, проте, поглядає в бік обох письменників не з однаковим інтересом.

На сайтах з творами Гоголя «комп’ютерний математик» фіксував у рік 200-ліття письменника понад сім мільйонів відвідувань; нині ця цифра зросла до десяти мільйонів. На Шевченкові сайти зацікавлені читачі-дослідники заходять значно рідше, натомість із пам'ятниками цим геніям картина цілком протилежна. Загальна кількість пам'ятників Гоголю сягає близько сотні, а за рубежем нараховується всього п’ятнадцять. Більшість із них стоять в Україні, яка для Росії є також зарубіжжям. Тим часом Шевченко зводився на гранітний п’єдестал майже 1400 разів. 3 них в Україні - 1256, а за кордоном - 138. У питанні з Україною, то тут усе більш-менш ясно: починаючи з 1922 року, коли було прийнято відповідну постанову ще українською радянською владою, пам'ятник Кобзареві мав би стояти в кожному українському місті та у більшому селі. Цю постанову виконують в Україні, по суті, до сьогоднішнього дня. Тому й така цифра: 1256. Щодо зарубіжжя, то маємо таку статистику: 10 пам'ятників Шевченку встановлено в Росії; 16 - у Казахстані, по 9 - у Канаді і США, 6 - у Білорусії, 5 - у Польщі, 4 - в Молдові, 3 - у Франції і т.д. Найвище пам'ятний знак поетові встановлено на Кавказі. У 1939 році група альпіністів під керівництвом заслуженого майстра спорту, дніпропетровця Олександра Зюзіна здійснила сходження в Центральному Кавказі. Одну з вершин на висоті 4200 метрів альпіністи назвали «Пік Шевченка». У 1964 році група українських альпіністів ініціювала друге сходження на цей пік. На так званому «Южмаші» 
був відлитий алюмінієвий пам'ятник Тарасу Григоровичу, який альпіністи i встановили на вершині гори. 9 березня 2014 року, коли відзначалося 200-ліття поета, до того пам’ятника на тій вершині дніпропетровські альпіністи поклали живі квіти. Подібне вшанування Гоголя, мабуть, ще попереду. Хоча існує й «песимістичний» погляд на це питання. Один із дослідників літератури зауважує, що інтерес до творчості Гоголя з роками спадатиме. Цей письменник, мовляв, потребує інтелектуального читача, а де ти його сьогодні візьмеш? Адже теле- та комп'ютеризація розумової «бездіяльності» людини нині працює не на розквіт, а на деградацію інтелекту як такого. Питання, звичайно, дискусійне, воно однаковою мірою стосується і рецепції Шевченка, який теж потребує інтелекту. Хоча велику роль відіграє, звичайно, і суто почуттєвий елемент: до Шевченка, крім розуму, потужно тягнеться насамперед душа людини; налаштована вона, звичайно, на патріотизм в Україні, але й на природний в людині світовий інтернаціоналізм. Расул Гамзатов колись говорив, що Шевченка ми особливо шануємо за те, що він свого часу проблему Кавказу розумів значно глибше, ніж ми його розуміємо сьогодні. А американський художник і письменник Рокуел Кент подібну думку уточнював у такий спосіб: «Я американський художник $і$ американецьь плоттю та кров'ю, але те, щуо я бачив з творів Шевченка-художника, $i$ те, щзо я знаю про нього як про поета, викликає найглибші чуття щзиого захоплення його талантом $і$ творчістю. Я пишаюся цчими творами, немовби я сам украӥнец̧ь. Вам Шевченко - цуе мій Шевченко» [Кент 1964:314]. Подібні висловлювання, звичайно, належать до емоційних. Вони не завжди підкріплюються аналітизмом, але не зважати на них все одно не можна: емоції ж бо завжди передують аналітичній роботі людського інтелекту. Як, скажімо, в такому випадку: один із представників магічної прози в латиноамериканській літературі А. Карпентьєр, глянувши колись на прекрасний краєвид, що спостерігається 3 київської Володимирської гірки, майже вигукнув: «Ось де взявся Гоголь!». Тим часом, аналітики давно вже показали: магічна проза латиноамериканців найбезпосередніше пов'язана саме 3 феноменом творчості Гоголя. Дехто вказує i на «точку» їхньої 
взаємопов'язаності: самотність. Нобелівська промова лідера латиноамериканців Маркеса, мовляв, тому й називалася «Самотність Латинської Америки». А Гоголь же - найбільш самотня в літературі постать [Каразін 2013]. Так воно, та не зовсім так. У власному житті Гоголь справді бував інколи дуже самотнім, але «духовна самість» характерна (на думку деяких дослідників) i для Шевченка [Смілянська 2015:5]. Проте творчість обох геніїв не замкнулася на них самих, на їхній самості, а сягнула всіх земних континентів. Не всі фахівці, щоправда, усвідомлюють, що Гоголь таки геній України $\mathrm{i}$ його місце в українській ієрархії має стояти тільки поруч 3 іншим українським генієм Шевченком. Найважче сказати, коли в це повірять насамперед ті науковці в Росії, хто Гоголя привласнив собі раз і назавжди. Мабуть, не повірять ніколи. Особливо, коли «глухо» триматимуться за сказане М. Чернишевським: «Mbl не знаем, как могла бы Россия обойтись без Гоголя». Або почнуть зважувати на терезах (як зважували написане Шевченком) i встановлювати, скільки кілограмів гоголівського тексту написано російською мовою. А українською ж, мовляв, лише кілька цитат із народних пісень, нової української літератури та одна записка до польського письменника Богдана Залеського...

\section{БІБЛІОГРАФІЯ}

Гуковский 1959 - Гуковський Г. Реализм Гоголя / Г. Гуковський Ленинград, 1959.

Каразін 2013 - Казарин В. Одиночество Николая Гоголя / В. Каразин // День. - 2013. - 12 октября.

Кент 1964 - Кент Р. Пишаюся його творами / Р. Кент // Світова велич Шевченка: збірник матеріалів про творчість Т. Г. Шевченка в трьох томах. T. 3. - K., 1964.

Маланюк 1962 - Маланюк Є. Книга спостережень. Проза. / Є. Маланюк. Торонто, 1962. - С. 197.

Мандельштам 1902 - Мандельштам И. О характере гоголевского стиля : Глава из истории русского литературного языка. - Гельсингфорс, 1902.

Новые стихотворения Пушкина и Шевченко. - Лейпциг, 1859. 
Смілянська 2015 - Смілянська В. Сучасна рецепція феномену Тараса Шевченка (неоміфологічний аспект) / В. Смілянська // Слово і час. - 2015. № 5 .

Шевченко 2003 - Шевченко Т. Повне зібрання творів у 12 томах, т. 5. K., 2003.

Шевченко 2003 - Шевченко Т. Повне зібрання творів у 12 томах, т. 6. K., 2003.

http://ukrkniga.org.ua/ukrkniga-text/794/.

http://www.dissertac.com/content/nv-gogol... 